Check for updates

Cite this: Chem. Sci., 2020, 11, 201

๑ All publication charges for this article have been paid for by the Royal Society of Chemistry

Received 23rd September 2019 Accepted 1st November 2019

DOI: $10.1039 / c 9 s c 04786 \mathrm{~g}$

rsc.li/chemical-science

\section{Extraction and transport of sulfate using macrocyclic squaramide receptors $\dagger$}

\author{
Lei Qin, (D) a Sacha J. N. Vervuurt, ${ }^{a}$ Robert B. P. Elmes, (D) ab Stuart N. Berry, (D) a \\ Nicholas Proschogo ${ }^{a}$ and Katrina A. Jolliffe (iD *a
}

\begin{abstract}
The selective extraction of the hydrophilic sulfate ion from water is highly challenging because the high free energy of hydration of this ion makes it more difficult to extract than less hydrophilic ions such as chloride and nitrate. Lipophilic macrocyclic squaramide receptors 1 and 2 were synthesized. Receptor 2 efficiently extracted sulfate from aqueous sodium sulfate solutions into a chloroform phase, via exchange with nitrate ions, overcoming the Hofmeister bias. The resulting $2 \cdot \mathrm{SO}_{4}{ }^{2-}$ complex was readily recycled through precipitation of $\mathrm{BaSO}_{4}$. Transport of sulfate across a bulk chloroform membrane by 2 was demonstrated across a wide $\mathrm{pH}$ range $(\mathrm{pH} 3.2-9.4)$ and in the presence of high concentrations of competing anions (chloride, nitrate and dihydrogenphosphate), opening the door to the use of 2 for the selective removal of sulfate from water across a range of applications.
\end{abstract}

\section{Introduction}

The development of selective receptors capable of extracting sulfate from aqueous solution is of significant interest because of the important roles this anion plays in biological, environmental and industrial processes. ${ }^{1}$ The removal of sulfate from aqueous solution is of particular importance in oil production and desalination processes where sulfate ions contribute to the formation of scale that clogs pipes and fouls membranes. ${ }^{2-4}$ It is also of relevance in the nuclear industry where sulfate interferes with the vitrification process required for safe long-term storage of nuclear waste, primarily as a result of the low solubility of sulfate in borosilicate glass. ${ }^{5-7}$ Precipitation of $\mathrm{BaSO}_{4}$ is frequently used to remove sulfate from solution, but this approach is problematic in removing sulfate from nuclear waste as a result of the co-precipitation of radioactive ${ }^{228} \mathrm{Ra} /{ }^{226} \mathrm{Ra}$ and ${ }^{90} \mathrm{Sr}$ ions forming $\mathrm{Ba}(\mathrm{Ra}) \mathrm{SO}_{4}$ and $\mathrm{Ra}\left(\mathrm{Sr}_{\mathrm{C}} \mathrm{SO}_{4} \cdot{ }^{8-10}\right.$ Therefore, it has been proposed that the selective extraction of sulfate from nitrate rich solutions by liquid-liquid extraction (LLE) using synthetic receptors could have significant benefits for nuclear waste remediation. ${ }^{11}$

Despite the need to selectively extract sulfate from aqueous media, several key challenges have hindered the development of selective sulfate extraction agents. Sulfate has a very high hydration energy $\left(\Delta G_{\text {hyd }}=-1080 \mathrm{~kJ} \mathrm{~mol}^{-1}\right),{ }^{12}$ which poses

${ }^{a}$ School of Chemistry, The University of Sydney, NSW 2006, Australia. E-mail: kate. jolliffe@sydney.edu.au

${ }^{b}$ Department of Chemistry, Maynooth University, National University of Ireland, Maynooth, Co., Kildare, Ireland

$\dagger$ Electronic supplementary information (ESI) available: Synthetic procedures and characterisation data for all new compounds; general methods and data for sulfate extraction and transport experiments. See DOI: 10.1039/c9sc04786g a dual challenge for selective extraction of this anion from aqueous solution. Firstly, to extract sulfate from an aqueous phase into an organic phase, a receptor needs to bind sulfate with high affinity to compensate for the large dehydration energy. Secondly, if other anions such as nitrate, are present in high concentrations and are less strongly hydrated $\left(\Delta G_{\text {hyd }}=\right.$ $\left.-306 \mathrm{~kJ} \mathrm{~mol}^{-1}\right)^{12}$ than sulfate, these are easier to extract from aqueous solution than sulfate (commonly referred to as Hofmeister bias) reducing sulfate extraction efficiency. To overcome this bias and allow sulfate extraction in the presence of less hydrophilic anions, receptors must have excellent selectivity for sulfate. A further important challenge lies in the release of sulfate following extraction to allow facile recycling of the receptors and enable commercially viable industrial processes. $^{11}$

While a number of receptors for selective sulfate recognition have recently been reported, ${ }^{13-25}$ there are relatively few examples of suitable receptors that overcome the Hofmeister bias to allow LLE of sulfate. ${ }^{26-33}$ Sessler and co-workers have successfully employed calix $[n]$ pyrroles to extract sulfate into organic media in the presence of methyltrialkylammonium ions. ${ }^{26-28}$ $\mathrm{Wu}$ and co-workers have demonstrated that a tripodal hexaurea receptor is capable of extraction of sulfate ions into chloroform solution in the presence of TBACl and that the sulfate can be back-extracted with aqueous barium chloride to regenerate the receptor as a chloride complex..$^{30}$ Moyer and coworkers have demonstrated that a simple diiminoguanidinium extractant demonstrates very high sulfate selectivity and compatibility with aliphatic solvents commonly used in LLE processes..$^{31}$ More recently, Romanski and coworkers have demonstrated that a ditopic receptor extracts potassium sulfate from aqueous solution. ${ }^{33}$ In related work, the transport of sulfate across 
a bilayer membrane has been shown to be facilitated by tripodal thioureas. ${ }^{17}$ However, receptors that can transport sulfate across a bulk liquid membrane to facilitate receptor recycling for realworld applications of sulfate extraction remain unexplored.

We have recently reported the use of macrocyclic squaramides as highly selective sulfate receptors with strong affinity for this anion in aqueous mixtures ${ }^{34}$ and reasoned that these macrocycles could be readily modified with aliphatic chains to solubilize them in organic solvents without altering their sulfate binding affinity, thereby enabling efficient and selective LLE of sulfate ions and their transport across a bulk liquid membrane. We now demonstrate that suitably functionalized macrocyclic squaramides are able to extract sulfate from aqueous solutions of sodium sulfate across a wide $\mathrm{pH}$ range $(\mathrm{pH} 3.2-9)$ and are capable of sulfate-nitrate exchange, overcoming the Hofmeister bias. We also show for the first time that dynamic sulfate transport can be achieved across a bulk liquid membrane in the presence of competing anions, demonstrating efficient receptor recyclability.

\section{Results and discussion}

The structures of macrocyclic squaramides (MSQs) 1 and $\mathbf{2}$ are based on our previously reported sulfate selective receptor 3

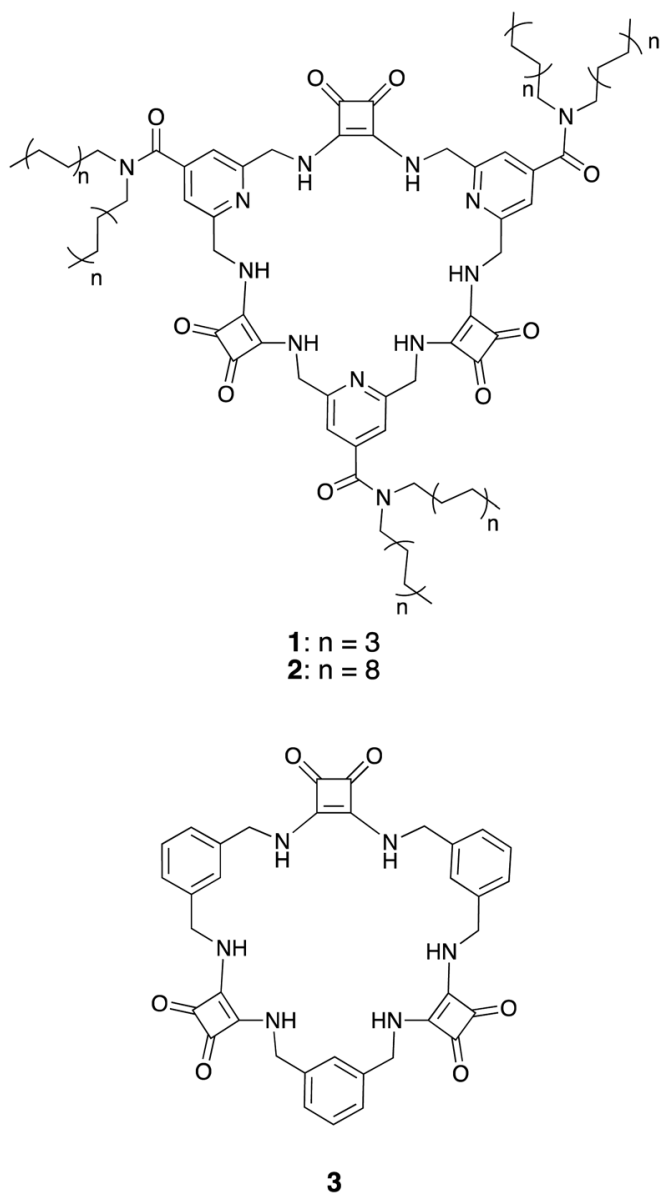

Chart 1 Structures of the MSQs 1-3.
(Chart 1). In concurrent work, ${ }^{35}$ we have demonstrated that replacing the benzene spacers in 3 with pyridines provides increased sulfate binding affinity, particularly at low $\mathrm{pH}$ where protonation of the pyridine units can occur, without reducing the selectivity that these macrocycles display for sulfate. We therefore chose to use isonicotinamide derived macrocycles in this work. We reasoned that it should be possible to functionalize this macrocyclic core with aliphatic chains to solubilize the macrocycle in organic solvents without impacting the demonstrated high sulfate binding affinity and selectivity of the macrocyclic core.

\section{Synthesis}

The synthesis of macrocycles $\mathbf{1}$ and $\mathbf{2}$ followed similar procedures to those described previously for the synthesis of MSQs (Scheme 1). ${ }^{34}$ Briefly, basic hydrolysis of methyl 2,6-bis(azido) isonicotinate ${ }^{36,37}$ was followed immediately by reaction of the resulting carboxylic acid with either dioctylamine or dioctadecylamine in the presence of carbodiimide (CDI) to give diazides 4 and 5, respectively. Staudinger reduction of 4 and 5 to form the corresponding diamines 6 and 7 was followed by reaction with two equivalents of diethyl squarate to give disquarates $\mathbf{8}$ and 9, respectively. Following mono-Boc protection of diamines $\mathbf{6}$ and 7, the so-formed amines $\mathbf{1 0}$ and $\mathbf{1 1}$ were immediately reacted with 0.5 equivalents of diethyl squarate in ethanol to give the diisonicotinamide squaramides $\mathbf{1 2}$ and $\mathbf{1 3 .}$ Deprotection of compound $\mathbf{1 2}$ upon treatment with trifluoroacetic acid and subsequent reaction of diamine 14 with the corresponding disquarate 8 in ethanol provided the desired [3] MSQ 1 in 56\% yield over the two steps. In contrast, attempts to condense diamine $\mathbf{1 5}$ with disquarate $\mathbf{9}$ under the same conditions were unsuccessful. However, in a mixed solvent system of EtOH/toluene/hexane (10:45:45 v/v/v) to ensure the solubility of all starting materials and reduce the aggregation of the long alkyl chains, ${ }^{\mathbf{3 8 , 3 9}} \mathbf{9}$ and $\mathbf{1 5}$ were successfully condensed in the presence of one equivalent of $\mathrm{TBAH}_{2} \mathrm{PO}_{4}$ to form [3]MSQ 2 in 58\% yield. We found that dihydrogen phosphate was crucial for the formation of [3] MSQ 2; the addition of a range of other anions $\left(\mathrm{Cl}^{-}, \mathrm{ClO}_{4}{ }^{-}, \mathrm{I}^{-}, \mathrm{BF}_{4}{ }^{-}, \mathrm{SO}_{4}{ }^{2-}\right)$ did not lead to isolation of the desired product. In the absence of an anion or in the presence of anions such as $\mathrm{ClO}_{4}{ }^{-}, \mathrm{I}^{-}, \mathrm{BF}_{4}{ }^{-}$that are known to only weakly coordinate to squaramides, ${ }^{\mathbf{3 0 , 4 0 , 4 1}}$ no reaction occurred. In the presence of $\mathrm{Cl}^{-}$and $\mathrm{SO}_{4}{ }^{2-}$, which bind to squaramides with relatively high affinities, mixtures of products were observed but all attempts to isolate desired macrocycle 2 (or other discrete species) from these reactions failed. We hypothesize that $\mathrm{Cl}^{-}$and $\mathrm{SO}_{4}{ }^{2-}$ may bind strongly to the reactants in the non-polar conditions used, ${ }^{\mathbf{4 0 - 4 4}}$ locking them into conformations that do not favour cyclisation, thus promoting the formation of linear oligomers, whereas the weaker binding to $\mathrm{H}_{2} \mathrm{PO}_{4}{ }^{-}$allows interconversion of conformers to allow cyclisation to progress.

\section{Sulfate extraction}

We first established that appending alkyl chains to the MSQs did not impact their previously observed ability to bind with 


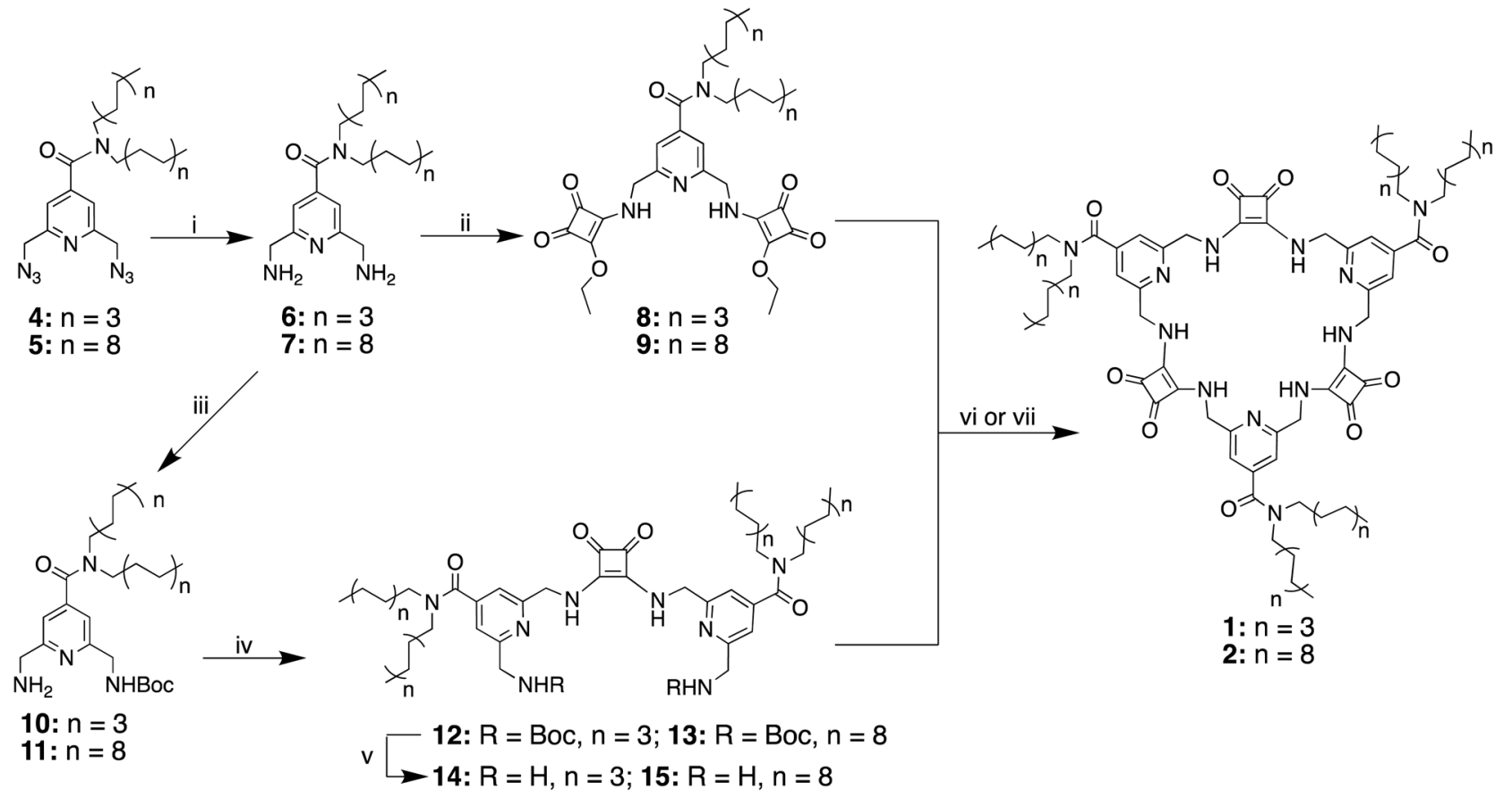

Scheme 1 Synthesis of the macrocyclic squaramide based receptors 1 and 2. Conditions: (i) $\mathrm{Ph}_{3} \mathrm{P}, \mathrm{H}_{2} \mathrm{O}, \mathrm{THF},(6,79 \%$; 7, 85\%); (ii) diethyl squarate, $\mathrm{EtOH}, \mathrm{RT}, 16 \mathrm{~h},(8,82 \% ; 9,79 \%)$; (iii) $\mathrm{Boc}_{2} \mathrm{O}, \mathrm{CH}_{2} \mathrm{Cl}_{2}, \mathrm{RT}, 16 \mathrm{~h},(10,49 \% ; 11,62 \%$ ); (iv) diethyl squarate, EtOH, RT, 16 h (12, 46\%; 13, 60\%); (v) TFA/ $\mathrm{CH}_{2} \mathrm{Cl}_{2}, \mathrm{RT}, 2 \mathrm{~h}$ (14, quant.; 15, quant.); (vi) $8+14$, EtOH, RT, 48 h, (1, 56\%); (vii) $9+15, \mathrm{TBAH}_{2} \mathrm{PO}_{4}, \mathrm{EtOH} /$ toluene/hexane $10 / 45 / 45 \mathrm{v} / \mathrm{v} / \mathrm{v}, 60{ }^{\circ} \mathrm{C}$, $48 \mathrm{~h}(2,58 \%)$.

high affinity to sulfate ions. ${ }^{34}$ In water-saturated $\mathrm{CDCl}_{3}$, the signal attributable to the squaramide NH protons of MSQ 2 is too broad to observe and the signal for the benzylic protons occurs as a broad multiplet indicating the presence of multiple slowly interconverting conformers of the macrocycle. ${ }^{34}$ Titration of $\mathrm{TBA}_{2} \mathrm{SO}_{4}$ into a solution of 2 in $\mathrm{H}_{2} \mathrm{O}$-saturated $\mathrm{CDCl}_{3}$ led to a sharpening and downfield shift of the signal attributable to the squaramide $\mathrm{NH}$ with the appearance of a new signal at $\delta 9.50 \mathrm{ppm}$ after the addition of 1 equiv. of $\mathrm{SO}_{4}{ }^{2-}$ that further sharpened into a triplet on addition of excess $\mathrm{SO}_{4}{ }^{2-}$ (Fig. S25 $\dagger$ ). A sharpening and upfield shift of the signal attributable to the aromatic protons, together with a sharpening and downfield shift of the signal attributable to the benzylic protons were also observed. This indicates the formation of a $2 \cdot \mathrm{SO}_{4}{ }^{2-}$ complex in $\mathrm{CDCl}_{3}$ with intermediate/slow exchange, suggesting strong binding $\left(K_{\mathrm{a}}>10^{4} \mathrm{M}^{-1}\right)$ under these conditions. Titration of $\mathrm{TBANO}_{3}$ into a solution of 2 in $\mathrm{H}_{2} \mathrm{O}$-saturated $\mathrm{CDCl}_{3}$ resulted in similar changes to the spectra, however the downfield shift of the signal attributable to the squaramide proton was significantly lower than that observed upon addition of sulfate, with this signal emerging at $\delta 8.16 \mathrm{ppm}$ after addition of 1 equiv. of nitrate, again suggesting strong $1: 1$ binding $\left(K_{\mathrm{a}}>10^{4} \mathrm{M}^{-1}\right)$ under these conditions.

The ability of $\mathbf{1}$ and $\mathbf{2}$ to extract sulfate from aqueous solution using liquid-liquid extraction was next investigated by vigorously shaking an aqueous solution of $\mathrm{TBA}_{2} \mathrm{SO}_{4}$ (see ESI $\uparrow$ for details) with a $\mathrm{CDCl}_{3}$ solution of either 1 or $2[45 \mathrm{mM}]$ for 1 minute. The two layers were immediately separated and the organic phase analysed by ${ }^{1} \mathrm{H}$ NMR. For MSQ 1, ${ }^{1} \mathrm{H}$ NMR spectroscopy indicated that none of the MSQ remained in the organic phase. However, a precipitate formed in the aqueous layer and after filtration and redissolution in $\mathrm{CDCl}_{3}$, analysis of the precipitate by ${ }^{1} \mathrm{H}$ NMR (Fig. S28 $\dagger$ ) indicated the presence of $\mathrm{TBA}^{+}$and $1 \cdot \mathrm{SO}_{4}$ in a $2: 1$ ratio, as established through integration of the macrocycle and $\mathrm{TBA}^{+}$signals, together with the chemical shift of the squaramide $\mathrm{NH}$ protons matching that observed in the titration experiments above. This indicates the formation of a $\mathrm{TBA}_{2}\left[\mathbf{1} \cdot \mathrm{SO}_{4}\right]$ complex, confirming the $1: 1$ complexation stoichiometry and suggesting that, while $\mathbf{1}$ is capable of binding to $\mathrm{SO}_{4}{ }^{2-}$ at an aqueous-organic interface, the resulting complex is not sufficiently soluble in $\mathrm{CDCl}_{3}$ to extract the $\mathrm{SO}_{4}{ }^{2-}$ into the organic phase. ${ }^{29}$ In contrast, with the more lipophilic MSQ 2, analysis of the $\mathrm{CDCl}_{3}$ phase after liquidliquid extraction indicated that one equiv. of $\mathrm{TBA}_{2} \mathrm{SO}_{4}$ was extracted into the organic phase, as determined by comparison of the integrations of the signals attributable to the macrocycle and tetrabutylammonium counterion which gave a ratio of 2 $\mathrm{TBA}^{+}$ions per macrocycle (Fig. S30 and S31†). Notably, 2 was capable of efficient sulfate extraction, even at substoichiometric sulfate concentrations (Fig. S31†). However, the lipophilic tetrabutylammonium counter ions were required for efficient extraction to take place, as attempts to extract $\mathrm{Na}_{2} \mathrm{SO}_{4}$ under the same conditions were unsuccessful.

We next evaluated the ability of MSQ 2 to extract sulfate in the presence of nitrate ions using an anion metathesis approach in which aqueous solutions of $\mathrm{Na}_{2} \mathrm{SO}_{4}$ at either $\mathrm{pH} 3.2$ or $\mathrm{pH} 7.4$ were layered onto a solution of [3]MSQ 2 and 2.0 eq. $\mathrm{TBANO}_{3}$ in $\mathrm{CDCl}_{3}$ (pH of the aqueous phase was adjusted using 
conc. $\mathrm{HNO}_{3}$ ). The two layers were vigorously shaken for 1 minute, then separated and the organic phases were analyzed using ${ }^{1} \mathrm{H}$ NMR (Fig. 1). The ${ }^{1} \mathrm{H}$ NMR signals corresponding to the $2 \cdot \mathrm{NO}_{3}{ }^{-}$and $2 \cdot \mathrm{SO}_{4}{ }^{2-}$ complexes are clearly differentiated by the chemical shift of the $\mathrm{NH}$ signals and appeared independently in $1: 10$ and $3: 10$ ratios of $2 \cdot \mathrm{SO}_{4}{ }^{2-}: 2 \cdot \mathrm{NO}_{3}{ }^{-}$at $\mathrm{pH} 7.4$ and $\mathrm{pH} 3.2$, respectively. This indicates that there is slow exchange between the $\mathbf{2} \cdot \mathrm{NO}_{3}{ }^{-}$and $2 \cdot \mathrm{SO}_{4}{ }^{2-}$ complexes under these conditions. We speculate that the relative higher proportion of $2 \cdot \mathrm{SO}_{4}{ }^{2-}$ formed under acidic conditions is due to the partial protonation of the pyridine units in the macrocycle at $\mathrm{pH} 3.2$ as the $\mathrm{p} K_{\mathrm{a}}$ of isonicotinamide is $3.3,{ }^{45}$ which results in increased sulfate binding affinity. ${ }^{34}$ The $2 \cdot \mathrm{SO}_{4}{ }^{2-}$ complex in $\mathrm{CDCl}_{3}$ was readily recycled to the nitrate complex upon washing with an aqueous solution of $\mathrm{Ba}\left(\mathrm{NO}_{3}\right)_{2}$ (Fig. 2d) as a result of the formation of $\mathrm{a} \mathrm{BaSO}_{4}$ precipitate $\left(K_{\mathrm{sp}}=1.1 \times 10^{-10}, 25^{\circ} \mathrm{C}\right) \cdot{ }^{46}$ These experiments demonstrate that MSQ 2 is capable of sulfate-nitrate exchange processes at an aqueous-organic interface, indicating that the excellent selectivity demonstrated by MSQ 2 for $\mathrm{SO}_{4}{ }^{2-}$ overcomes the Hofmeister bias and eliminates the need for lipophilic counter ions in the aqueous phase.

\section{Sulfate transport across a bulk liquid membrane}

We next investigated the ability of 2 to transport sulfate across a bulk chloroform membrane using classic Cram U-tube experiments (Fig. 2), ${ }^{, 47-49}$ as proof of principle that the receptor is capable of the dynamic removal of sulfate from aqueous solution through an anion exchange mechanism. In initial experiments the aqueous source and receiving phases were buffered to $\mathrm{pH} 7.4$ (20 mM Tris) with the source phase also containing $500 \mathrm{mM} \mathrm{Na} \mathrm{SO}_{4}$ and the bulk chloroform phase containing $10 \mathrm{mM} 2$. Sulfate concentrations in both the source

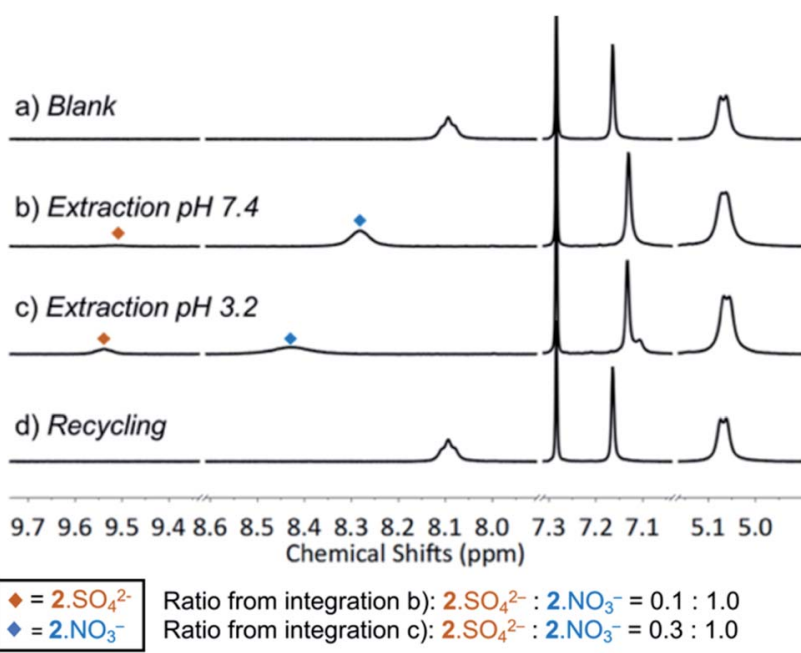

Fig. 1 Partial ${ }^{1} \mathrm{H}$ NMR spectra $(400 \mathrm{MHz})$ of a $\mathrm{CDCl}_{3}$ solution of MSQ 2 $(5 \mathrm{mM})$ and $\mathrm{TBANO}_{3}(10 \mathrm{mM})$ after extraction of the following aqueous solutions: (a) blank (20 mM Tris buffer, pH 7.4); (b) $500 \mathrm{mM} \mathrm{Na}_{2} \mathrm{SO}_{4}$ in $20 \mathrm{mM}$ Tris buffer, $\mathrm{pH} 7.4$; (c) $500 \mathrm{mM} \mathrm{Na}_{2} \mathrm{SO}_{4}$ in $20 \mathrm{mM}$ Tris buffer, $\mathrm{pH}$ 3.2, adjusted by addition of conc. $\mathrm{HNO}_{3}$; (d) back extraction of solution (c) through washing with $100 \mathrm{mM}$ aqueous $\mathrm{Ba}\left(\mathrm{NO}_{3}\right)_{2}$. Back extraction of solution (b) gave an identical spectrum.

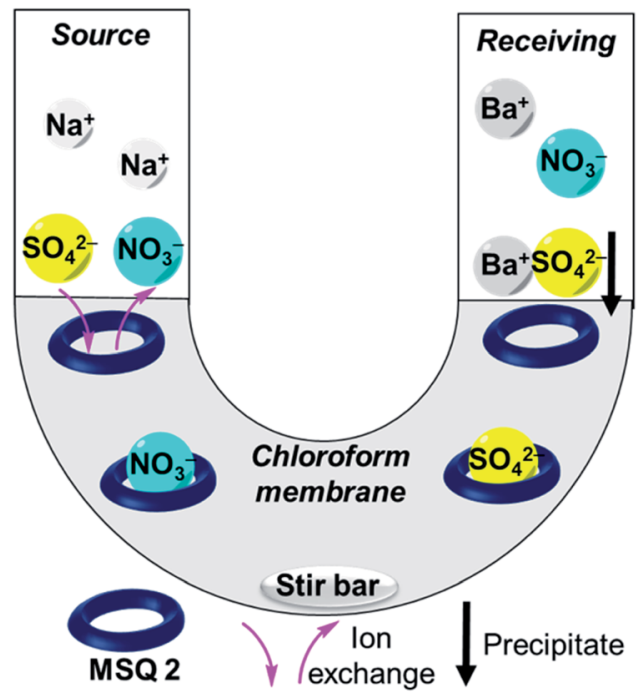

Fig. 2 Illustration of $U$-tube transport experiment (TBA ${ }^{+}$cations are omitted for clarity).

and receiving phases were detected using a modified $\mathrm{BaSO}_{4}$ gravimetric analysis method ${ }^{50,51}$ in which the non-precipitated $\mathrm{Ba}^{2+}$ concentration was measured using inductively coupled plasma mass spectrometry (ICP-MS) after the formation of a $\mathrm{BaSO}_{4}$ precipitate. The final sulfate concentrations in each experiment were also determined by ICP-MS by measuring the

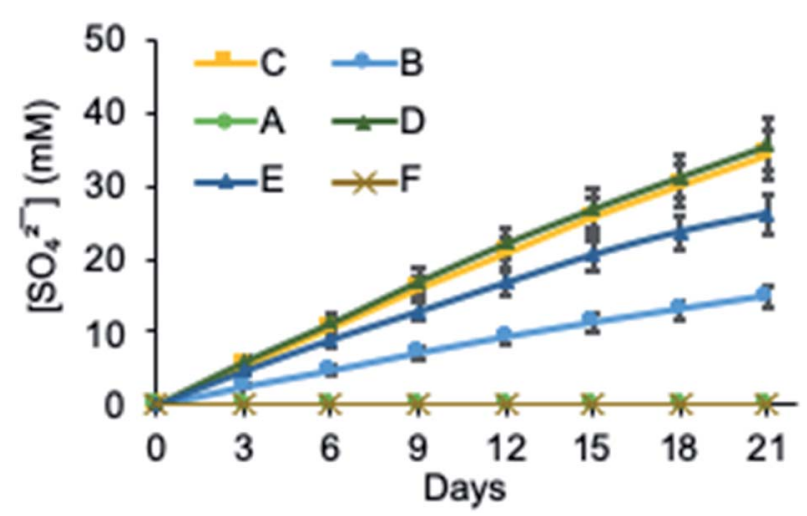

Fig. 3 Sulfate transport by 2 across a bulk chloroform membrane determined by the $\left[\mathrm{SO}_{4}{ }^{2-}\right]$ in the receiving phase. Conditions: (A) source phase $500 \mathrm{mM} \mathrm{Na}_{2} \mathrm{SO}_{4}$ in $20 \mathrm{mM}$ Tris buffer ( $\mathrm{pH}$ 7.4); receiving phase $20 \mathrm{mM}$ Tris buffer ( $\mathrm{pH} 7.4$ ); organic phase $10 \mathrm{mM} 2$ in $\mathrm{CHCl}_{3}$. (B) Source phase $500 \mathrm{mM} \mathrm{Na}_{2} \mathrm{SO}_{4}$ in $20 \mathrm{mM}$ Tris buffer ( $\mathrm{pH}$ 7.4); receiving phase $20 \mathrm{mM}$ Tris buffer ( $\mathrm{pH} 7.4)$; organic phase $10 \mathrm{mM} 2$ and $50 \mathrm{mM}$ $\mathrm{TBANO}_{3}$ in $\mathrm{CHCl}_{3}$. (C) Source phase $500 \mathrm{mM} \mathrm{Na}_{2} \mathrm{SO}_{4}$ in $20 \mathrm{mM}$ Tris buffer (pH 7.4); receiving phase $300 \mathrm{mM} \mathrm{BaCl}_{2}$ in $20 \mathrm{mM}$ Tris buffer $(\mathrm{pH}$ 7.4); organic phase $10 \mathrm{mM} 2$ and $50 \mathrm{mM} \mathrm{TBANO}_{3}$ in $\mathrm{CHCl}_{3}$. (D) Source phase $500 \mathrm{mM} \mathrm{Na}_{2} \mathrm{SO}_{4}$ in $\mathrm{H}_{2} \mathrm{O}\left(\mathrm{pH} 3.2, \mathrm{HNO}_{3}\right)$; receiving phase $300 \mathrm{mM} \mathrm{BaCl}_{2}$ in $\mathrm{H}_{2} \mathrm{O}\left(\mathrm{pH} 3.2, \mathrm{HNO}_{3}\right)$; organic phase $10 \mathrm{mM} 2$ and $50 \mathrm{mM} \mathrm{TBANO}_{3}$ in $\mathrm{CHCl}_{3}$. (E) source phase $500 \mathrm{mM} \mathrm{Na}_{2} \mathrm{SO}_{4}$ in $\mathrm{H}_{2} \mathrm{O}$ $(\mathrm{pH}$ 9.4, $\mathrm{NaOH})$; receiving phase $300 \mathrm{mM} \mathrm{BaCl}_{2}$ in $\mathrm{H}_{2} \mathrm{O}(\mathrm{pH}$ 9.4, $\mathrm{NaOH}$ ); organic phase $10 \mathrm{mM} 2$ and $50 \mathrm{mM} \mathrm{TBANO}_{3}$ in $\mathrm{CHCl}_{3}$. (F) source phase $500 \mathrm{mM} \mathrm{Na}_{2} \mathrm{SO}_{4}$ in $20 \mathrm{mM}$ Tris buffer ( $\mathrm{pH}$ 7.4); receiving

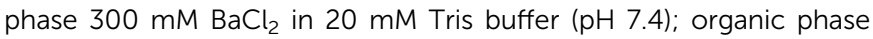
$50 \mathrm{mM} \mathrm{TBANO}_{3}$ in $\mathrm{CHCl}_{3}$. 
concentration of sulfide (Table S2 $\dagger$ ). ${ }^{52,53}$ In the absence of any ion source in the organic phase, no transport was observed after 21 days (Fig. 3 and Table S2†), indicating that MSQ 2 is not capable of transporting $\mathrm{Na}_{2} \mathrm{SO}_{4}$ across a bulk liquid membrane. However, upon the addition of five equivalents, relative to the receptor, of $\mathrm{TBANO}_{3}$ (tetraalkylammonium ions have previously been shown to facilitate sulfate extraction through formation of ion pair complexes ${ }^{27}$ ) to the chloroform phase, a sulfate concentration of $15 \mathrm{mM}$ (all data listed in Table S2 $\dagger$ ) was detected in the receiving phase after 21 days. No sulfate was detected in the receiving phase in the absence of receptor 2 . These results indicate that 2 is capable of efficiently transporting the highly hydrophilic sulfate ion across a bulk liquid membrane with subsequent release into an aqueous phase via an anion exchange mechanism.

In subsequent experiments, $\mathrm{BaCl}_{2}$ was added to the receiving phase. We anticipated this would facilitate sulfate release though precipitation of $\mathrm{BaSO}_{4}$, thereby removing sulfate from the receiving phase and increasing transport rates through Le Chatelier's principle. This resulted in a $>2$-fold increase in the amount of sulfate transported over the same time period. No change in transport rate was observed upon lowering the $\mathrm{pH}$ to 3.2 , whereas increasing the $\mathrm{pH}$ to 9.4 resulted in a modest reduction in sulfate transport. This may be due to the reduced binding affinity of the isonicotinamide MSQ core at basic $\mathrm{pH}^{35}$ or alternatively might be a result of increased competition from carbonate ions at this higher $\mathrm{pH}$. There was no detectable change in the concentration of sodium ions in the source or receiving phases in any of the transport experiments confirming that, under these conditions, transport occurs via an anion metathesis process. Finally, we evaluated sulfate transport with a mixture of anions in the source phase that mimics that in nuclear waste $\left(100 \mathrm{mM} \mathrm{Na}_{2} \mathrm{SO}_{4}, 100 \mathrm{mM} \mathrm{Na} \mathrm{HPO}_{4}, 500 \mathrm{mM}\right.$ $\mathrm{NaNO}_{3}, 500 \mathrm{mM} \mathrm{NaCl}, \mathrm{pH}$ 7.4). Under these highly competitive conditions, 2 still exhibited sulfate transport, although the rate was diminished, reflecting the ability of 2 to bind strongly to other anions in chloroform (Table S5†). While we have previously established that water-soluble analogues of 2 and related macrocycles bind sulfate with higher affinity than other anions in polar solvents (such as $1: 1 \mathrm{v} / \mathrm{v} \mathrm{DMSO} / \mathrm{H}_{2} \mathrm{O}$ ), ${ }^{34,35}$ in relatively non-polar solvents such as chloroform, 2 binds to nitrate, chloride and sulfate with $K_{\mathrm{a}}>10^{4}$ for all three ions. Since both transport and extraction experiments require binding to occur at the interface between the water and chloroform phases, our hypothesis is that the demonstrated higher affinity of the macrocyclic core of 2 for sulfate over other anions in aqueous media results in preferential binding of sulfate by 2 at the aqueous interface, leading to the observed extraction and transport behaviour.

\section{Experimental}

\section{Synthesis of macrocycle 1}

Compound $12(76 \mathrm{mg}, 0.07 \mathrm{mmol})$ was dissolved in a solution of $\mathrm{TFA} / \mathrm{CH}_{2} \mathrm{Cl}_{2}(1: 1 \mathrm{v} / \mathrm{v}, 3 \mathrm{~mL})$ before the reaction mixture was stirred at room temperature for 2 hours and then concentrated under reduced pressure. The resulting oil was dissolved in
EtOH $(3 \mathrm{~mL})$ then a solution of $8(46 \mathrm{mg}, 0.07 \mathrm{mmol})$ and $\mathrm{Et}_{3} \mathrm{~N}$ $(0.5 \mathrm{~mL})$ in EtOH $(50 \mathrm{~mL})$ was added and the resulting mixture was stirred at room temperature for $48 \mathrm{~h}$. The solvent was then removed under reduced pressure to give a yellow oil. Subjection of this material to flash silica gel chromatography $(5 / 95 \mathrm{v} / \mathrm{v}$ methanol/dichloromethane elution) and concentration of the appropriate fractions $\left(R_{\mathrm{f}} 0.3\right)$ gave the macrocycle $1(57 \mathrm{mg}$, $56 \%)$ as a beige solid. Mp. $262-268{ }^{\circ} \mathrm{C}$ (decomp.); ${ }^{1} \mathrm{H}$ NMR (400 MHz, DMSO- $\left.d_{6}\right): 0.79-0.90(\mathrm{~m}, 18 \mathrm{H}), 0.98-1.29(\mathrm{~m}, 60 \mathrm{H}), 1.41(\mathrm{~s}$, $6 \mathrm{H}), 1.56(\mathrm{~s}, 6 \mathrm{H}), 3.04(\mathrm{~s}, 6 \mathrm{H}), 3.36(\mathrm{~s}, 6 \mathrm{H}), 4.81(\mathrm{~s}, 12 \mathrm{H}), 7.23(\mathrm{~s}$, $6 \mathrm{H}), 8.02$ (br s, $6 \mathrm{H}) ;{ }^{13} \mathrm{C}$ NMR $\left(100.6 \mathrm{MHz}\right.$, DMSO$\left.-d_{6}\right): 14.3,14.4$, 22.4, 22.5, 26.3, 26.8, 27.4, 28.4, 28.9, 29.1, 29.2, 29.5, 31.6, 31.7, 44.5, 48.6, 118.2, 146.8, 158.2, 168.3, 183.3, 2 signals obscured or overlapping; HRMS (ESI, MeOH) calcd for $\mathrm{C}_{84} \mathrm{H}_{126} \mathrm{~N}_{12} \mathrm{O}_{9} \mathrm{Na}$ $[\mathrm{M}+\mathrm{Na}]^{+} 1447.9845$, found 1447.9829; $\nu_{\max }$ (film) per $\mathrm{cm}^{-1}$ : 3237 (broad), 2925, 2851, 1801, 1714, 1609.

\section{Synthesis of macrocycle 2}

Compound 13 (53 $\mathrm{mg}, 0.032 \mathrm{mmol}$ ) was dissolved in a solution of TFA $/ \mathrm{CH}_{2} \mathrm{Cl}_{2}(1: 1 \mathrm{v} / \mathrm{v}, 3 \mathrm{~mL})$ and the reaction mixture was stirred at room temperature for 2 hours, then concentrated under reduced pressure. The solid was washed with $5 \%$ $\mathrm{NaHCO}_{3}$ solution $(5 \mathrm{~mL})$ then dried under stream of $\mathrm{N}_{2}(\mathrm{~g})$. The resulting solid was dissolved in $20 \mathrm{~mL}$ toluene and then added to a solution of $9(30 \mathrm{mg}, 0.032 \mathrm{mmol})$ and $\mathrm{TBAH}_{2} \mathrm{PO}_{4}(10.8 \mathrm{mg}$, $0.032 \mathrm{mmol})$ in EtOH/toluene/hexane 10/45/45 v/v/v $(500 \mathrm{~mL})$ and stirred at $60{ }^{\circ} \mathrm{C}$ for $48 \mathrm{~h}$. The solvent was then removed under reduced pressure to give a yellow solid. Subjection of this material to flash silica gel chromatography $(1 / 99$ to $5 / 95 \mathrm{v} / \mathrm{v}$ methanol/dichloromethane elution) and concentration of the appropriate fractions $\left(R_{\mathrm{f}} 0.3\right)$ gave compound $2(42 \mathrm{mg}, 58 \%)$ as a beige solid. Mp. $252-258{ }^{\circ} \mathrm{C}$ (decomp.); ${ }^{1} \mathrm{H}$ NMR (400 MHz, $\left.\mathrm{CDCl}_{3}\right): 0.86(\mathrm{t}, J=6.8 \mathrm{~Hz}, 18 \mathrm{H}), 0.98-1.41(\mathrm{~m}, 180 \mathrm{H}), 1.38-1.55$ (m, 6H), 1.55-1.69 (m, 6H), $3.08(\mathrm{t}, J=7.7 \mathrm{~Hz}, 6 \mathrm{H}), 3.42(\mathrm{t}, J=$ $7.7 \mathrm{~Hz}, 4 \mathrm{H}), 4.9(\mathrm{br} \mathrm{s}, 12 \mathrm{H}), 7.1(\mathrm{~s}, 6 \mathrm{H}), 7.7(\mathrm{br} \mathrm{s}, 6 \mathrm{H}) ;{ }^{13} \mathrm{C} \mathrm{NMR}$ $\left(100.6 \mathrm{MHz}, \mathrm{CDCl}_{3}\right): \delta 189.29,183.18,177.99,172.37,168.08$, 155.74, 147.20, 147.20, 118.25, 69.92, 48.98, 44.97, 31.92, 29.70, 29.65, 29.46, 29.41, 29.35, 29.19, 28.75, 27.46, 27.08, 26.68, 26.62, 22.68, 15.86, 14.10; HRMS (ESI, MeOH) calcd for $\mathrm{C}_{144} \mathrm{H}_{246} \mathrm{~N}_{12} \mathrm{O}_{9} \mathrm{H}_{2}[\mathrm{M}+2 \mathrm{H}]^{2+}$ 1144.9653, found 1144.9645; $\nu_{\max }$ (film) per $\mathrm{cm}^{-1}$ : 3254 (broad), 2920, 2851, 1807, 1598, 1535, 1466.

\section{Conclusions}

In summary, we have shown that the neutral MSQ 2 can efficiently extract $\mathrm{SO}_{4}{ }^{2-}$ from an aqueous $\mathrm{Na}_{2} \mathrm{SO}_{4}$ solution into organic solution, via an anion exchange mechanism with nitrate ions, overcoming the Hofmeister bias. This is attributed to the high binding affinity of $\mathbf{2}$ for sulfate ions. We have further successfully demonstrated that, assisted by a lipophilic cation, MSQ 2 can transport the highly hydrophilic sulfate ion across a bulk chloroform layer via an anion exchange mechanism with nitrate, allowing the extraction of sulfate from sodium sulfate solutions. Notably, receptor 2 is able to transport sulfate across a bulk chloroform membrane even when a complex mixture of 
anions is present and across a wide $\mathrm{pH}$ range ( $\mathrm{pH}$ 3.2-9.4). Release of the sulfate from the receptor into the receiving phase is facilitated through precipitation of $\mathrm{BaSO}_{4}$ thereby increasing the rate of sulfate transport. These results provide proof-ofprinciple that neutral receptors for the sulfate ion can be employed in the selective removal of sulfate from aqueous solution in a recyclable manner, overcoming one of the key limitations for the use of such receptors in real-world applications such as the removal of sulfate from nuclear waste.

\section{Conflicts of interest}

There are no conflicts to declare.

\section{Acknowledgements}

This work was supported by an Australian Research Council Discovery Project grant (DP170100118).

\section{Notes and references}

1 I. Ravikumar and P. Ghosh, Chem. Soc. Rev., 2012, 41, 30773098.

2 M. S. H. Bader, Desalination, 2006, 201, 100-105.

3 K. M. Abdullaev, M. M. Agamaliev and D. A. Akhmedova, J. Water Chem. Techno., 2019, 41, 119-124.

4 L. F. Greenlee, D. F. Lawler, B. D. Freeman, B. Marrot and P. Moulin, Water Res., 2009, 43, 2317-2348.

5 B. A. Moyer and R. P. Singh, Fundam. Appl. Anion Sep., Springer, 2004.

6 E. A. Katayev, Y. A. Ustynyuk and J. L. Sessler, Coord. Chem. Rev., 2006, 250, 3004-3037.

7 R. K. Mishra, K. V. Sudarsan, P. Sengupta, R. K. Vatsa, A. K. Tyagi, C. P. Kaushik, D. Das and K. Raj, J. Am. Ceram. Soc., 2008, 91, 3903-3907.

8 T. Y. Zhang, K. Gregory, R. W. Hammack and R. D. Vidic, Environ. Sci. Technol., 2014, 48, 4596-4603.

9 P. Medley, P. Martin, A. Bollhöfer and D. Parry, Appl. Radiat. Isot., 2015, 95, 200-207.

10 F. Grandia, J. Merino and J. Bruno, Assessment of the radiumbarium co-precipitation and its potential influence on the solubility of $\mathrm{Ra}$ in the near-field, Technical Report TR-08-07, Swedish Nuclear Fuel and Waste Management Co., Stockholm, 2008.

11 B. A. Moyer, R. Custelcean, B. P. Hay, J. L. Sessler, K. Bowman-James, V. W. Day and S. O. Kang, Inorg. Chem., 2013, 52, 3473-3490.

12 R. Custelcean and B. A. Moyer, Eur. J. Inorg. Chem., 2007, 2007, 1321-1340.

13 C. Jin, M. Zhang, L. Wu, Y. Guan, Y. Pan, J. Jiang, C. Lin and L. Wang, Chem. Commun., 2013, 49, 2025-2027.

14 R. B. P. Elmes, K. K. Y. Yuen and K. A. Jolliffe, Chem.-Eur. J., 2014, 20, 7373-7380.

15 H. Zhou, Y. Zhao, G. Gao, S. Li, J. Lan and J. You, J. Am. Chem. Soc., 2013, 135, 14908-14911.

16 V. J. Dungan, H. T. Ngo, P. G. Young and K. A. Jolliffe, Chem. Commun., 2013, 49, 264-266.
17 N. Busschaert, L. E. Karagiannidis, M. Wenzel, C. J. E. Haynes, N. J. Wells, P. G. Young, D. Makuc, J. Plavec, K. A. Jolliffe and P. A. Gale, Chem. Sci., 2014, 5, 1118-1127.

18 A. Schaly, R. Belda, E. Garcia-Espana and S. Kubik, Org. Lett., 2013, 15, 6238-6241.

19 Z. Rodriguez-Docampo, E. Eugenieva-Ilieva, C. Reyheller, A. M. Belenguer, S. Kubik and S. Otto, Chem. Commun., 2011, 47, 9798-9800.

20 J. L. Sessler, E. Katayev, G. D. Pantos and Y. A. Ustynyuk, Chem. Commun., 2004, 1276-1277.

21 P. A. Gale, J. R. Hiscock, C. Z. Jie, M. B. Hursthouse and M. E. Light, Chem. Sci., 2010, 1, 215-220.

22 C. Jia, Q. Q. Wang, R. A. Begum, V. W. Day and K. BowmanJames, Org. Biomol. Chem., 2015, 13, 6953-6957.

23 J. I. Kim, H. Juwarker, X. Liu, M. S. Lah and K. S. Jeong, Chem. Commun., 2010, 46, 764-766.

24 P. Mateus, R. Delgado, V. Andre and M. Teresa Duarte, Org. Biomol. Chem., 2015, 13, 834-842.

25 N. A. Tzioumis, K. K. Y. Yuen and K. A. Jolliffe, Supramol. Chem., 2018, 30, 667-673.

26 C. J. Fowler, T. J. Haverlock, B. A. Moyer, J. A. Shriver, D. E. Gross, M. Marquez, J. L. Sessler, M. A. Hossain and K. Bowman-James, J. Am. Chem. Soc., 2008, 130, 1438614387.

27 C. J. Borman, R. Custelcean, B. P. Hay, N. L. Bill, J. L. Sessler and B. A. Moyer, Chem. Commun., 2011, 47, 7611-7613.

28 S. K. Kim, J. Lee, N. J. Williams, V. M. Lynch, B. P. Hay, B. A. Moyer and J. L. Sessler, J. Am. Chem. Soc., 2014, 136, 15079-15085.

29 L. R. Eller, M. Stępień, C. J. Fowler, J. T. Lee, J. L. Sessler and B. A. Moyer, J. Am. Chem. Soc., 2007, 129, 11020-11021.

30 C. Jia, B. Wu, S. Li, X. Huang, Q. Zhao, Q. S. Li and X. J. Yang, Angew. Chem., Int. Ed., 2011, 50, 486-490.

31 N. J. Williams, C. A. Seipp, K. A. Garrabrant, R. Custelcean, E. Holguin, J. K. Keum, R. J. Ellis and B. A. Moyer, Chem. Commun., 2018, 54, 10048-10051.

32 B. Akhuli, I. Ravikumar and P. Ghosh, Chem. Sci., 2012, 3, 1522-1530.

33 D. Jagleniec, L. Dobrzycki, M. Karbarz and J. Romanski, Chem. Sci., 2019, 10, 9542-9547.

34 L. Qin, A. Hartley, P. Turner, R. B. P. Elmes and K. A. Jolliffe, Chem. Sci., 2016, 7, 4563-4572.

35 L. Qin, J. R. Wright, J. D. E. Lane, S. N. Berry, R. B. P. Elmes and K. A. Jolliffe, Chem. Commun., 2019, 55, 12312-12315.

36 S. G. Gouin, M. Roger, N. Leygue, D. Deniaud, K. Julienne, E. Benoist, C. Picard, J. Kovensky and C. Galaup, Bioorg. Med. Chem. Lett., 2012, 22, 2684-2688.

37 L. Laurent, B. Hervé and B. Emilie, Novel rare earth element cryptates including a tetraazatriphenylene unit, WO 2010070232, 2008.

38 R. O. Dunn and M. O. Bagby, J. Am. Oil Chem. Soc., 1995, 72, 123-130.

39 R. O. Dunn and M. O. Bagby, J. Am. Oil Chem. Soc., 1994, 71, 101-108.

40 V. E. Zwicker, K. K. Yuen, D. G. Smith, J. Ho, L. Qin, P. Turner and K. A. Jolliffe, Chem.-Eur. J., 2018, 24, 1140-1150. 
41 V. Amendola, G. Bergamaschi, M. Boiocchi, L. Fabbrizzi and M. Milani, Chem.-Eur. J., 2010, 16, 4368-4380.

42 V. Amendola, L. Fabbrizzi, L. Mosca and F. P. Schmidtchen, Chem.-Eur. J., 2011, 17, 5972-5981.

43 N. Busschaert, I. L. Kirby, S. Young, S. J. Coles, P. N. Horton, M. E. Light and P. A. Gale, Angew. Chem., Int. Ed., 2012, 51, 4426-4430.

44 R. B. Elmes, P. Turner and K. A. Jolliffe, Org. Lett., 2013, 15, 5638-5641.

45 J. L. Castro, J. F. Arenas, M. R. Lopez-Ramirez, J. Soto and J. C. Otero, J. Colloid Interface Sci., 2013, 396, 95-100.

46 C. C. Templeton, J. Chem. Eng. Data, 1960, 5, 514-516.

47 D. J. Cram, Angew. Chem., Int. Ed., 1988, 27, 1009-1020.
48 G. M. Ritcey, Tsinghua Sci. Technol., 2006, 11, 137-152.

49 G. M. Ritcey and A. W. Ashbrook, Solvent Extraction: Principle and Applications to Process Metallurgy, Part I, Elsevier, Amsterdam, 1984.

50 O. K. Galle and L. R. Hathaway, Appl. Spectrosc., 1975, 29, 518-519.

51 F. Torrades and M. Castellvi, Fresenius. J. Anal. Chem., 1994, 349, 734-737.

52 M. Colon, M. Iglesias, M. Hidalgo and J. L. Todoli, J. Anal. At. Spectrom., 2008, 23, 416-418.

53 P. R. Craddock, O. J. Rouxel, L. A. Ball and W. Bach, Chem. Geol., 2008, 253, 102-113. 